\title{
高強度の間欠的トレーニングとウエイトトレーニングが最大酸菜借と 最大酸素摄取量に与える影響
}

\author{
平井雄 介* 田畑泉**
}

\section{EFFECT OF HIGH INTENSITY INTERMITTENT TRAINING AND RESISTANCE TRAINING ON THE MAXIMAL OXYGEN DEFICIT AND $\dot{\mathrm{V} \mathrm{O}_{2} \max }$}

\author{
YuUSUKE HiRai and IzUmi Tabata
}

\begin{abstract}
This study examined the effects of (1) an intermittent training using a mechanically braked cycle ergometer and (2) resistance training using free weight on the maximal oxygen deficit and $\dot{\mathrm{V}}_{2}$ max. For the first 6 weeks, six subjects trained using an intermittent training protocol five days per week. The exhaustive intermittent training consisted of seven to eight sets of $20 \mathrm{~s}$ exercise at an intensity of about $170 \%$ of $\dot{\mathrm{V}}_{2} \mathrm{max}$ with a $10 \mathrm{~s}$ rest between each bout. After the training, the maximal oxygen deficit increased significantly from $64.3 \pm 5.0 \mathrm{ml} \cdot \mathrm{kg}^{-1}$ to $75.1 \pm 5.7 \mathrm{ml} \cdot \mathrm{kg}^{-1}(\mathrm{p}<0.01)$, while $\dot{\mathrm{V}} \mathrm{O}_{2} \mathrm{max}$ increased from $52.0 \pm 2.7 \mathrm{ml} \cdot \mathrm{kg}^{-1} \cdot \mathrm{min}^{-1}$ to $57.6 \pm 2.9 \mathrm{ml} \cdot \mathrm{kg}^{-1} \cdot \mathrm{min}^{-1}(\mathrm{p}<0.05)$. For the following 6 weeks, the subjects used the same intermittent training for 3 days per week and a resistance training for the other 3 days per week. The resistance training consisted of (1) 4 sets of 12 bouts of squat and leg curl exercise at 12 repetition maximum (RM). (2) 2 sets of maximal bouts of the same exercise with a load of $90 \%, 80 \%$, and $70 \%$ of $1 \mathrm{RM}$. After the training period, the maximal oxygen deficit increased further to the value of $86.8 \pm 5.9 \mathrm{ml} \cdot \mathrm{kg}^{-1}$ which was significantly higher than the value attained at the end of the intermittent training. On the other hand, $\dot{\mathrm{V}} \mathrm{O}_{2}$ max did not increase significantly from the value observed at the end of the 6 weeks of intermittent training. Body weight was not significantly changed throughout the 12-week training period. Maximal circumference of the thigh did not changed during the first 6 -week of the intermittent training period (pre-training : 57.1 $\pm 1.2 \mathrm{~cm}$, after 6 -week training: $57.3 \pm 1.1 \mathrm{~cm}$ ), while it increased significantly after the last 6-week combined training $(59.0 \pm 0.8 \mathrm{~cm}, \mathrm{p}<0.05)$. In conclusion, this study showed that (1) high intensity intermittent training improves both the anaerobic and aerobic energy supplying systems, (2) additional resistance training with the intermittent training further increases the anaerobic energy supplying system, probably through increased muscle mass.
\end{abstract}

(Jpn. J. Phys. Fitness Sports Med. 1996, 45, 495 502)

key words : intermittent training, resistance training, maximal oxygen deficit, $\mathrm{V}_{2}$ max.

\section{I . 粕}

1 分程度で疲労困恶に至るようなミドルパワー の運動では，総エネルギー需要量に対する無酸素 性と有酸素性エネルギー供給機構の貢献度が, ほ ほ等しい6.9)。したがって，ミドルパワーの運動 が主であるようなスポーツ競技では，無酸素性お よび有酸素性エネルギー供給能力とも競技成績を
左右する要因になると考えられる．有酸素性エネ ルギー供給機構の最大能力はエネルギー供給速度 の上限である最大酸素捸取量 $\left(\dot{\mathrm{V}} \mathrm{O}_{2} \mathrm{max}: 1 / \mathrm{min}\right)$ に よって評価される。一方, 無酸素性エネルギー供 給機構の最大能力は最大酸素借によって評価され $3^{5,6,8,9)}$. 最大酸素借は, $2 \sim 3$ 分程度で疲労困 䣏に至るような運動中の総酸素借 (Accumulated oxygen deficit) として測定され, 無酸素性エネル
*株式会社キャピタルチヨダスポーツ, スポーティングソサエティ・ナンバーワン 下 168 東京都杉並区下高井戸5-14-6

**国立健康 - 栄養研究所健康增進部運動生理研究室 ₹162 東京都新宿区戸山1-23-1
Sporting Society No. 1, Capital Chiyoda Sports Corporation, 5-14-6 Shimotakaido, Suginami Tokyo 168, Japan.

Laboratory for Exercise Physiology, Division of Health Promotion, National Institute of Health and Nutrition, 1-23-1 Toyama, Shinjuku Tokyo 162, Japan. 
ギー供給機㯨から供給されるエネルギー量の最大 値を示す ${ }^{8)}$. 運動中に酸素借の蓄積量が最大に達 すると, 無酸素性エネルギー供給機構からのエネ ルギー供給が停止し, 疲労困㷛に至る。したがっ て，トレーニングによる最大酸素借の增加はミド ルパワーの運動能力を向上させると考えられる.

これまで，最大酸素攝取量に対するトレーニンク 効果に関する研究は数多く行われている.しかし， 最大酸素借は測定方法が最近確立されたため5), それに対するトレーニング効果を見たものは少な ( 9.20 ).

最大酸素借の大きさを決定する要因は，質的に は筋における乳酸の産生量とクレアチンリン酸の 分解量であり ${ }^{8.9 .10)}$ ，量的には活動筋量1,13.14) と 考えられている．また, より多くの乳酸の産生を 可能にするのは筋の緩衝能力の向上によると考え られている ${ }^{12,15,18)}$. Tabata たち ${ }^{20)}$ は，運動中の 総酸素借が最大酸素借に達するように構成された 約 $170 \% \mathrm{VO}_{2} \max$ の強度の間欠的運動を用いたト レーニング(間欠的トレーニング)を 6 週間実施し たところ, 最大酸素借は約 $28 \%$ 増加し, その増加 は主に筋の緩衝能力の向上が要因であったことを 示唆している.しかし，トレーニングによる活動 筋量の増加が，最大酸素借に与える影䈉を見たも のはない，筋量を生理学的に増加させる方法の一 つに, ウエイトトレーニングが挙げられる. 本研 究では, 先行研究により最大酸素借および最大酸 素捸取量を増加させることが明らかにされた間欠 的トレーニンクを行った被検者の無酸素性エネル ギー供給機構の最大能力をさらに増加させること を目的として，間欠的トレーニングに下肢筋群の ウエイトトレーニングを加えた場合の最大酸素借 および最大酸素搨取量の変化を観察した。

\section{II . 実漠手順 ・方法}

\section{A. 被検者}

本研究の被検者は, 健康な成人男子 6 名であり, 年龄, 身長および体重(平均値士SE) はそれぞれ, $23 \pm 1$ 歳, $172 \pm 5 \mathrm{~cm}, 71 \pm 8 \mathrm{~kg}$ であった。実 験を開始するにあたり, 全ての被検者に本研究の 目的, 方法, 危険性を十分に説明し, 本研究への
参加の同意を得た。

\section{B . 測定手順, 方法}

各被検者の自転車エルゴメー夕運動における運 動強度と酸素攝取量の関係を明らかにするため に, 最大下強度で10分間の固定負荷運動を強度を 変えて合計10１5回行わせ，各々の酸素摄取量を 測定した.すなわち，この測定では10分間の固定 負荷運動を被検者 1 名について $3 \sim 4$ 日をかけて 行い，各々の試行毎に15３0分の休息を挟みなが ら，1日に 4 ～5 試行を行わせた。 1 日の内に同 じような強度が重らないように, 低強度, 中強度, 高強度が期間内に分散するように組み合わせた。 最大下強度の運動での, 運動強度と酸素攝取量の 関係を一次回帰直線に表した. トレーニング後に も全ての被検者に10分間の最大下運動を強度を変 えて $3 \sim 4$ 回行わせ, 運動強度と酸素攝取量の関 係にトレーニング前後で変化がないことを確認し た.

最大酸素捸取量, 最大酸素借, 最大脚筋パワー 測定は, 全て約 $50 \% \dot{\mathrm{VO}}{ }_{2} \max$ の強度で 20 分間の ウォーミングアップ後に行われた. 最大酸素捸取 量は, 約 $70 \% \mathrm{~V}_{2} \max$ の強度の 2 分間の運動に続 いて, 被検者に $2 \sim 4$ 分程度続けられる強度の運 動を疲労困僙に至るまで行わせ, 運動終了前 1 2 分間の酸素摂取量を 30 秒毎に測定して求めた. これを, 疲労困䣏に至るまでの運動時間が $2 \sim 4$ 分になる範囲内で強度を変えて $2 \sim 3$ 回, 日を変 えながら行わせ，各々の測定で得られた酸素攝取 量の最大值から, 最大下運動で得られた運動強度 と酸素摄取量の一次回帰直線からレベリングオフ を確認して最大酸素摄取量を求めた ${ }^{4)}$. 同時に運 動中の心電図をモニターし, 得られた心拍数の最 高値を最高心拍数とした.

最大酸素借は, Medbø と Tabata ${ }^{9)}$ の方法に従 い, $2 \sim 3$ 分程度で疲労困䣏に至るような強度 (約 $140 \% \mathrm{VO}_{2} \max$ )の運動の総酸素借として求めた。 疲労困偲の判定はペダリング速度 $90 \mathrm{rpm}$ を維持 できず，85 rpm 以下に低下した時とした．最大 酸素借の算出のため, 運動中の酸素攝取量をダグ ラスバック法にて30秒毎に測定し，運動中の総酸 素摄取量を求めた。最大酸素借の計算には, まず, 
$2 \sim 3$ 分程度で疲労困䣏に至るような運動の酸素 需要量 $(1 / \mathrm{min})$, 最大下運動で求めた運動強度 と酸素摄取量の一次回帰直線から外挿法によって 求めた。この酸素需要量に運動時間をかけて総酸 素需要量 (liters)を算出した。ここで求めた総酸 素需要量からダグラスバック法で測定した総酸素 摄取量を引き，総酸素借を求めた，最大酸素借の 測定には疲労困億に至る時間を 2 〜分にする必 要がある ${ }^{10)}$ 。したがって，トレーニング期間中 の最大酸素借の測定では, 疲労困䣏に至る時間が 2 〜分にになるように, 運動強度を徐々に増加 させた。 また，酸素借測定の運動終了時では採気 が短時間となり，呼気の採集量が少なくなる場合 があるので，死腔の影響をできるだけ少なくする ように，マウスピースとダグラスバックとの接続 をできるだけ短く $($ 約 $20 \mathrm{~cm})$ した。

最大酸素摄取量, 最大酸素借の測定には自転車 エルゴメータ(Monark 社製)を用い,ペダリング 速度は全て $90 \mathrm{rpm}$ とした。，心拍数は，日本光電 社製のハートレートモニターで記録した，酸素摂 取量は全てダグラスバック法によって測定した。 すなわち，採集した呼気ガスの $\mathrm{O}_{2}$ 及び $\mathrm{CO}_{2}$ 濃 度は質量分析器 (Perkin Elmer 社製 MGA-1100) で分析し, 呼気ガス量は乾式ガスメーター(品川 製作所製)で定量した。

最大朋筋パワーは, 電気ブレーキ式自転車エル ゴメータ (Combi 社製Powermax-V)にて10秒間の 自転車エルゴメー夕運動を最大努力で行わせて測 定した. 運動中の 1 秒毎の平均回転数の最大値 とペダルの負荷から最大パワーを求め, 最大脚筋 パワーとした。ペダルの負荷は体重の10\%とし，

日を変えて 2 回づつ測定して，高い方の值を採 用した。

大腿囲は被検者に立位をとらせ，右脚大腿部に おける水平位の最大周径囲をスチールメジャーに て測定して求めた，測定はすべて同一の検者が 行った.

\section{C. トレーニング方法}

トレーニング期間は12週間とし，被検者に 1 〜 6 週は自転車エルゴメータでの間欠的運動を, $7 \sim 12$ 週は間欠的運動と下肢筋群のウエイトト

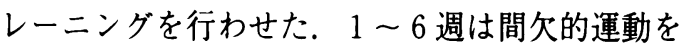
1 回/日，5 日/週の頻度で行わせた. 間欠的運動 は，まず $50 \% \mathrm{~V}_{2} \max$ の強度で20分間のウォーミ ングアップを行った。 その後, $170 \% \dot{V}_{2} \max の$ 強度で20秒間の運動を，10秒間の休息を挟んで疲 労困僵まで繰り返えさせた。このトレーニングで は運動を $7 〜 8$ 回行うことを目標とし，9回行う ことができた時には, 次回から運動強度を $11 \mathrm{~W}$ 増加させた。疲労困僵の目安は，ペダリング速 度 $90 \mathrm{rpm}$ を10秒間維持できなくなった時点とし た。ただし, 週 5 日の内 1 日は $70 \% \mathrm{VO}_{2} \max$ 強度 で30分間のウォーミングアップの後，20秒間の運 動を 10 秒間の休息を挟んで 4 回だけ繰り返す間欠 的運動を行わせた。

$7 \sim 12$ 週は 6 週目までの自転車エルゴメータで の間欠的運動を 1 回/日，3 日/週に減らし，下肢 筋群のウエイトトレーニングを 1 回/日，3 日/週 の頻度で行わせた．筋肥大を生じるには最大筋力 の70\% 80\%の重量 (10～15回程度反復できる重 量：10〜15RM)で最大まで反復し，短時間の休 息を挟んで数セット繰り返す方法が有効であると 言われている ${ }^{23)}$ 。この方法ではセットが進むに つれて, 同一重量での反復が困難になるため, 重 量を漸隇し全てのセットとも10１5回の反復が行 われる。 そこで本研究では, 大腿部の筋量の増加 を目的として，スクワット及びレッグカール運動 を 1 セット 12 回, 30 秒の休息を挟んで 4 セット行 わせた。 負荷重量は毎セット12回の反復で挙上 が不可能になるよう $12 \mathrm{RM}$ とし，セットが進む 毎に徐々に減少させた。 さらにその後 3 分の休息 を与え, 連続して 3 段階の重量を各々最大努力で 行うセットを 2 セット行わせた。このセットでは 各段階とも $4 \sim 5$ 回の反復が可能な重量で挙上不 可能になるまでの反復を, 連続して 3 段階の重量 で繰り返した。重量の切り替えは 2 秒以内に行わ れ，1 セットの合計反復回数が12〜15回になるよ うにした。

\section{D. 統計好理}

結果は全て平均土標準誤差で示した。トレーニ ング経過に伴う変化は対応のある $\mathrm{t}$ 検定を行い, 危険率 $5 \%$ 未満を有意とした。 


\section{III. 结}

\section{果}

被検者の体重は，12週間を通じて有意な変化は 見られなかった。Fig. 1 にはトレーニングに用い た間久的運動の強度とスクワット運動のトレーニ ング 1 セット目の負荷重量 (12 RM)の変化を示し た.トレーニングとして行われた間欠的運動の強 度はトレーニング開始時に比べ， 6 週後，12週後

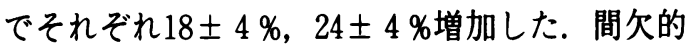
トレーニング開始後 7 週目から行ったスクワット 運動の $12 \mathrm{RM}$ の挙上重量は, トレーニング開始 時に比べ 6 週後には108土11\%增加した。

Fig. 2 にはトレーニングにともなう最大酸素借 の変化を示した，最大酸素借は12週間にわたって
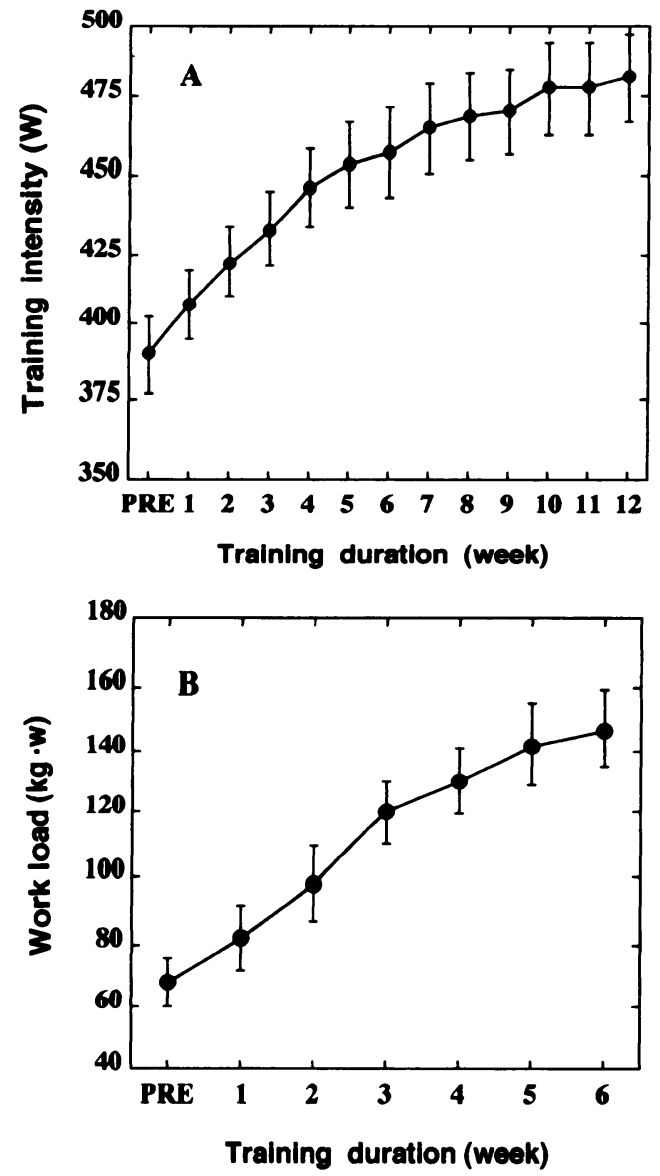

Fig. 1. Work rate used during the bicycie training period (A), and weight for the squat exercise during the resistance training period (B).

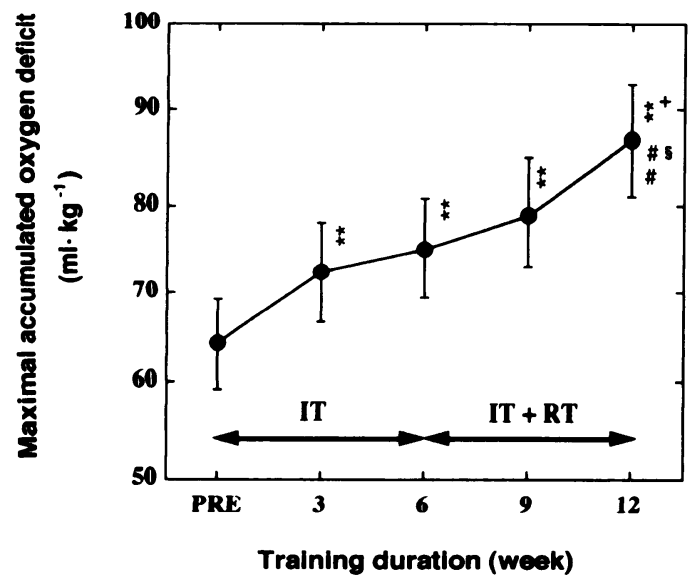

Fig. 2. Effect of the intermittent training (IT) and resistance training for legs ( $\mathrm{RT}$ ) on the maximal accumulated oxygen deficit. $*$ and $* *$ indicate a significant difference from the pre-training value at $\mathrm{p}<0.05$ and 0.01 , respectively. + and ++ indicate a significant difference from the $3 \mathrm{wk}$ value at $\mathrm{p}<0.05$ and 0.01 , respectively. \# and \#\# indicate a significant difference from the $6 \mathrm{wk}$ value at $\mathrm{p}<0.05$ and 0.01 , respectiyely. $\S$ and $\S \S$ indicate a significant difference from the $9 \mathrm{wk}$ value at $\mathrm{p}<0.05$ and 0.01 , respectively.

増加し，トレーニング前に比べ $3 ， 6 ， 9 ， 12$ 週

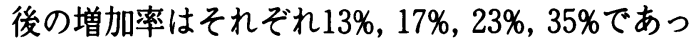
た. 最大酸素借はトレーニング開始直後の 3 週間 に急增し，さらに 9 週，12週とトレーニングが進 むにつれて増加率が上昇する傾向が認められた。 また, 最大酸素借を測定するためには疲労困僙に 至るまでの運動時間を 2 〜 分程度になるように する必要があるので, 運動強度をトレーニングの 経過に合わせて徐々に増加させて最大酸素借の測 定を行った。 その結果, 最大酸素借測定のために 行った運動の総仕事量は12週間にわたり有意に増 加した (Fig. 3).

最大酸素搷取量はトレーニング開始から 6 週後 まで徐々に増加したが $(11 \pm 2 \%)$ ，それ以後は有 意な変化は認められなった (Fig. 4). 最高心拍数 はトレーニング前後で有意な変化は認められな かった(トレーニング前 : $187 \pm 2 \mathrm{bpm}, 6$ 週後：

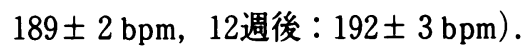

最大脚筋パワーは自転車エルゴメー夕運動のみ のトレーニングを 6 週間行っても変化しなかった 


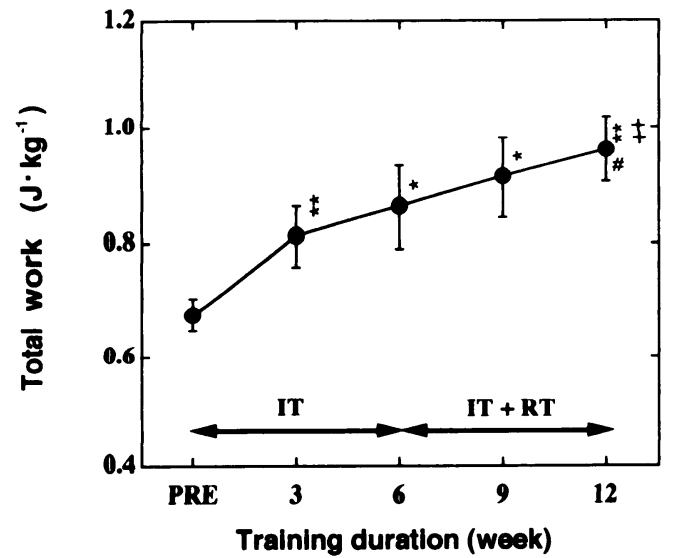

Fig. 3. Effect of the intermittent training (IT) and resistance training for legs $(\mathrm{RT})$ on the total mechanical work during $2 \sim 3 \mathrm{~min}$ exhaustive exercise. $*$ and $* *$ indicate a significant differ. ence from the pre-training value at $p<0.05$ and 0.01 , respectively. + and ++ indicate a significant difference from the $3 \mathrm{wk}$ value at $\mathrm{p}<0.05$ and 0.01 , respectively. \# and \# \# indicate a signi. ficant difference from the $6 \mathrm{wk}$ value at $\mathrm{p}<0.05$ and 0.01 , respectively. $\S$ and $\S \S$ indicate a significant differece from the 9 wk value at $\mathrm{p}<0.05$ and 0.01 , respectively.

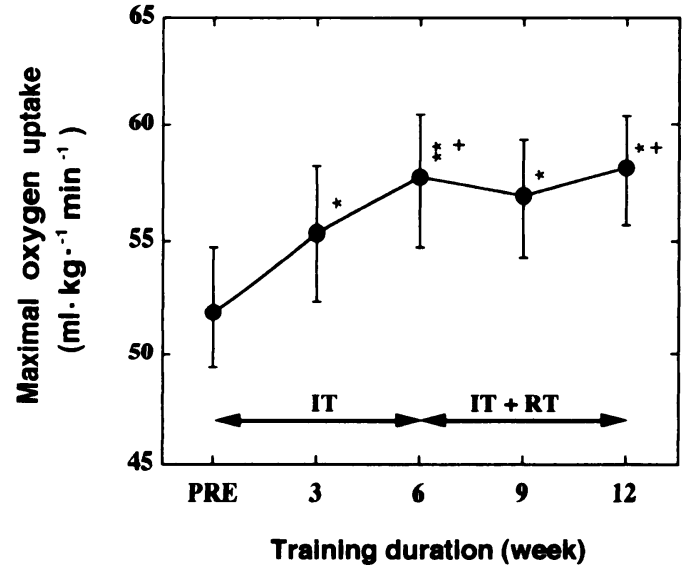

Fig. 4. Effect of the intermittent training (IT) and resistaining $(\mathrm{RT})$ on the maximal oxygen uptake. $*$ and $* *$ indicate a significant difference from the pre-training value at $\mathrm{p}<0.05$ and 0.01 , respectively. + and ++ indicate a significant difference from the $3 \mathrm{wk}$ value at $\mathrm{p}<0.05$ and 0.01 , respectively.

Table 1. Effects of training on maximal leg power output and circumference of thigh.

\begin{tabular}{lccc}
\hline & $\begin{array}{c}\text { Before } \\
\text { training }\end{array}$ & $\begin{array}{c}\text { After 6 wk } \\
\text { training }\end{array}$ & $\begin{array}{c}\text { After 12 wk } \\
\text { training }\end{array}$ \\
\hline \hline Max. power output, W/kg & $13.5 \pm 0.6$ & $13.6 \pm 0.5$ & $14.8 \pm 0.6^{*++}$ \\
Thigh girth,cm & $57.1 \pm 1.2$ & $57.3 \pm 1.1$ & $59.0 \pm 0.8^{*+}$ \\
\hline
\end{tabular}

Values are means $\pm \mathrm{SE} . *$ and $* *$ indicate a significant difference from pre-training value at the level of $p<0.05$ and $p<0.01$, respectively. + and ++ indicate a significant difference from the $6 \mathrm{wk}$ value at the level of $p<$ 0.05 and $\mathrm{p}<0.01$, respectively.

が，下肢筋郡のウエイトトレーニングを行った 12 週後ではトレーニング前より $10 \pm 3 \%$ 増加した $(\mathrm{p}<0.05$, Table 1)。また，大腿部の最大周径囲 も同様に 6 週後には変化がなかったのに対し，ウ エイトトレーニングを加えたトレーニング開始 12 週後ではトレーニング前より $3 \pm 1 \%$ 増加した $(\mathrm{p}<0.01$, Table 1).

\section{N. 考察}

\section{A ．無酸素性エネルギー供給能力への影䈏}

無酸素性エネルギー供給能力の最大值の指標と なる最大酸素借は， 6 週間で $18 \% ， 12$ 週間で $37 \%$ 増加した。この増加は，スプリントトレーニング を行った Medbøと Burgers ${ }^{7)}$ の結果より高い值 であった．本研究で用いた間欠的運動は運動中の 総酸素借が最大酸素借に達することが報告されて 
おり 20)，Medbøと Burgers ${ }^{7)}$ がトレーニングに用 いた運動によって生じる酸素借よりも大きい.ま た，横断的な研究によると，スプリントトレーニ ング群，持久性トレーニング群，非トレーニング 群の最大酸素借を比較し, トレーニング中に酸素 借が多く発生するスプリントトレーニング群で最 大酸素借が最も高く, 酸素借の発生が少ない持久 性トレーニング群と非トレーニング群では差がな いことが報告されている7 ${ }^{7.17)}$. したがって, 特定 のトレーニングによる最大酸素借の増加の度合い は,トレーニングとして行う運動によって生じる 酸素借の絶対值あるいは最大酸素借に対する相対 的割合が影響することが推察される。

最大酸素借に影響する因子として活動筋量の大 きさ ${ }^{1.13 .14)}$, 筋の緩衝能力 ${ }^{9.18)}$ および解糖系酵素 の活性の向上による乳酸産生能力の改善 ${ }^{12)}$ が挙 げられている. 本研究の前半の 6 週間のトレーニ ングでは大腿冊に変化が見られなかったことか ら, 筋量が増加したとは考えにくい.したがって, 前半の 6 週間における最大酸素借の増加は, 乳酸 産生能力および筋の緩衝能力の改善が主な要因で あったと推察される. 先行研究においても, 高強 度の運動を行うスプリントトレーニングによって 筋の緩衝能力が向上することが報告されてい $ろ^{15.16)}$.また, Nevill たち ${ }^{12)}$ はスプリントトレー ニングにより30秒の全力運動中の乳酸産生量が高 まったこと, 筋中から血中への $\mathrm{H}^{+}$流出が促進 され，筋中の $\mathrm{pH}$ の低下を抑制したことを示唆し ている.

一方，下肢筋群のウエイトトレーニングを間欠 的トレーニングに加えた本研究の後半の 6 週間の トレーニングにおいて, 最大酸素借の増加率が上 昇する傾向が認められた。 また, 最大脚筋パワー と大腿囲が共に増加し, 活動筋量の増加が示唆さ れた. 先行研究ではウエイトトレーニングにより 神経系の適応や motor unit の動員数の增加が確 かめられている311,16). Staron たち ${ }^{19)}$ はウエイ トトレーニング開始後 2 週から筋肥大の傾向を観 察したことを報告している。したがって，最大酸 素借が 9 週および 12 週後に増加率が上昇した理由 としては, 乳酸産生能力と筋の緩衝能力の向上に
加え, 活動筋量の増加にともなう総乳酸産生量の 增加も考えられる。

本研究の前半の自転車エルゴメー夕運動のみの トレーニングでは $170 \% \mathrm{VO}_{2} \max$ 強度 (約 40 秒程度 継続ができる強度)という高い強度で運動を 6 週 間を行った。しかし，最大脚筋パワーおよび大腿 囲の増加は認められなかった。一方, 間欠的トレー ニングに加えて, ウエイトトレーニングを負荷し た12週後には両者とも有意な増加が認められた。 この結果は，筋肥大および最大脚筋パワーの向上 には, ウエイトトレーニングのような高い張力発 揮が必要であることを示唆している.したがって, 本研究で対象としたような被検者では，170\% $\dot{\mathrm{V}} \mathrm{O}_{2} \max$ の強度でトレーニングを行っても筋量の 増大およびハイパワーの運動における最大発揮パ ワーの増加は望めないと考えられる。

\section{B．有酸素性エネルギー供給能力への影雷}

最大酸素攝取量はトレーニング開始後 6 週まで 有意な増加を示し，この増加は最大酸素借を測定 した超最大運動中の最高酸素摂取量にも反映して いた.

$\mathrm{Fox}^{2)}$ は,インターバルトレーニングにおいて 運動強度が高いほど最大酸素捸取量の増大が大き く，トレーニングの頻度や期間には左右されない ことを報告している，本研究のトレーニングで用 いた間久的運動は, 運動強度が $170 \% \mathrm{~V}_{2} \max$ と 高く，運動開始とともに急速に酸素攝取量が高ま る.そして, 間欠的運動の疲労困䣏時の酸素摄取 量は, ほほ最大酸素捸取量のレベルまで増加す $ろ^{22)}$. したがって, 本研究のトレーニングは有 酸素性エネルギー供給機構に対しても大きな負荷 を与えるものであり，最大酸素摄取量を増加させ たと考えられる。

しかし, 後半のトレーニングではトレーニング 強度が増加しても, 最大酸素摂取量は増加しな かった．その理由として, トレーニンク開始 6 週 以降, 最大酸素摂取量の増加が認められなかった 5 名の被検者の平均値が 6 週後の時点で約 60 $\mathrm{ml} / \mathrm{kg} / \mathrm{min}$ に達しており，各被検者のトレーナビ リティが低かったことが考えられる．実際，最大 酸素摂取量のレベルが低かった 1 名の被検者では 
トレーニング後半においても最大酸素摂取量が増 加した。しかし，最大酸素摂取量が変化しなかっ た要因には，単一のトレーニング様式の限界とも 考えられ，さらに増加させるためには異なるタイ プのトレーニングが必要なのかもしれない.

\section{C. 発揮エネルギー総量への影郵}

最大酸素借測定時の仕事量は, トレーニング前 に比べ 6 週後で $27 \%$ 増加し, 12 週後では 6 週後よ りさらに $11 \%$ 増加した. 2 - 3 分程度で疲労困借 に至るような運動では最大酸素借が得られる。つ まり，このような運動では無酸素性エネルギーの 供給が停止することによって, 運動の継続が不可 能になり, 疲労困僙に至る ${ }^{21)}$. 本研究のトレー ニング 6 週後には最大酸素借の増加と運動中の総 酸素捸取量の増加がいずれも認められた。した がって, トレーニング前半の総仕事量の増加，す なわち総エネルギー産生量の増加は, 最大酸素借 の増加に示される無酸素性のエネルギー供給量の 増加と有酸素性エネルギー供給能力の向上がいず れも影響したものと考えられる。

後半のトレーニングでは総酸素搨取量は増加し たが, 運動中の最高酸素搨取量は増加の傾向が認 められたものの有意な変化ではなかった。この総 酸素掑取量の増加は運動時間の延長によるもので あり, 有酸素性エネルギー供給能力の向上は認め られなかった。したがって, 後半の総仕事量の増 加は最大酸素借の増加が主な要因であると考えら れる.

本研究で用いた間欠的トレーニングは無酸素性 と有酸素性のエネルギー供給能力の両方を改善 し，また同時にウエイトトレーニングを加えるこ とにより，さらに無酸素性エネルギー供給能力を 改善した. その結果, $2 \sim 3$ 分程度で疲労困謈に 至るような運動中の総仕事量が増加した。した がって，このようなトレーニングを行えば，ミド ルパワーの運動を用いる競技のパフォーマンスを 改善する可能性があることが示唆された。

$$
\text { V.まと め }
$$

本研究の結果から, 高強度の間欠的トレーニン グで最大酸素借と最大酸素摂取量が増加した被検
者に，同時にウエイトトレーニングを加えること により,さらに最大酸素借が増加することが明ら かになった.

(受理日 平成 8 年 6 月 29 日)

\section{考支献}

1) Bangsbo, J., Michalsik, L., and Petersen A., Accumulated $\mathrm{O}_{2}$ deficit during intense exercise and muscle characteristics of elite athletes. Int. J. Sports Med., (1993), 14, 207-213.

2) Fox, E. L., Sports Physiology, 2 nd. Ed., HoltSaunders International Editions, New York, (1979), 238-241.

3) Hakkinen, K., Alen, M., and Komi, P. V., Changes in isometric force- and relaxation-time, electromyog. raphic and muscle fiber characteristics human skeletal muscle during strength training and detraining. Acta Physiol. Scand., (1985), 125, 573585.

4) Hermansen, L., Oxygen transport during maximal exercise in human subject. Acta Physiol. Scand., (1973), sappl. 399, 1-104.

5) Hermansen, L., Medb $\phi$, J. I., Mohn, A. -C., Tabata, I., Bahr, R., Anaerobic capacity determined by maximal oxygen deficit. Acta Physiol. Scand., (1984), 121, $39 \mathrm{~A}$.

6) 平井雄介, 小笠原悦子, 田畑 泉. 超最大強度の 水泳運動における無酸素性及び有酸素性エネル ギー供給機構の貢献度. Jpn. J. Sports Sci., (1993)。 12, 124-129.

7) Medb $\phi$, J. I., and Burgers, S., Effect of training on the anaerobic capacity. Med. Sci. Sports Exerc., (1990), 22, 501-507.

8) Medb $\phi$, J. I., Mohn, A. -C., Tabata, I., Bahr, R., Vaage, O., and Sejersted, O. M., Anaerobic capacity determined by maximal accumulated $\mathrm{O}_{2}$ deficit. J. Appl. Physiol., (1988), 64, 50-60.

9) Medb $\phi$. J. I., and Tabata, I., Relative importance of aerobic and anaerobic energy release during short-lasting exhausting exercise. J. Appl. Physiol., (1989), 67, 1881-1886

10) Medb $\phi$, J. I., and Tabata, I., Anaerobic energy release in working muscle during $30 \mathrm{~s}$ to $3 \mathrm{~min}$ of exhausting bicycling. J. Appl. Physiol., (1993), 75, 1654-1660.

11) Moritani, T., and DeVries, H. A., Neural factors versus hypertrophy in the time course of muscle strength gain. Am. J. Physiol. Med., (1979), 58, 115-130.

12) Nevill, M. E., Boobis, L. H., Brooks, S., and Wil liams, C., Effect of training on muscle metabolism during treadmill sprinting. J. Appl. Physiol., (1989), 67, 2376-2382.

13）荻田太, 田畑 泉, 平井雄介, 山奥慎一, 田口信教. 
スイムベンチ運動およびアームストロークにおけ る酸素借の最大値. 第44回日本体育学会大会号, (1993), 354.

14) Olesen, H. L., Accumulated oxygen deficit increases with inclination of uphill running. J. Appl. Physiol., (1992), 73, 1130-1134.

15) Sahlin, K., and Henriksson, J., Buffer capacity and lactate accumulation in skeletal muscle of trained and untrained men. Acta Phyiol. Scand., (1984), 122. 331-339.

16) Sale, D. G., Neural adaptation to resistance training. Med. Sci. Sports Exerc., (1988), 20, S 135-S 145.

17) Scott, C. B., Roby, F. B., Lohman, T. G., and Bunt, J. C., The maximally accumulated oxygen deficit as an indicator of anaerobic capacity. Med. Sci. Sports Exerc., (1991), 23, 618-624.

18) Sharp, R. L., Costill, D. L., and King, D. S., Effects of eight weeks of bicycle ergometer sprint training on human muscle buffer capacity. Int. J. Sports Med., (1986), 7, 13-17.

19) Staron, R. S., Karapondo, D. L., Kraemer, W. J., Fry, A. C., Gordon, S. E., Falkel, J. E., Hagerman, F. C., and Hikida, R. S., Skeletal muscle adaptations during early phase of heavy-resistance training in men and women. J. Appl. Physiol., (1994), 76, 1247-1255.

20) Tabata, I., Nishimura, K., Kouzaki, M., Hirai, Y., Ogita, F., Miyachi, M., Yamamoto, K., and Shibayama, H., Effects of moderate intensity, endurance and high intensity, intermittent training on anaerobic capacity and $\dot{\mathrm{V}}_{2}$ max. Med. Sci. Sports Exerc., in press.

21）田畑 泉. 無酸素性エネルギーの定量法. Jpn. J. Sports Sci., (1994), 13, 559-566.

22）田畑 泉，西村幸治. スピードスケート選手の陸 上トレーニングに用いられているインターバルト レーニングの代謝特性とその最大酸素攖取量およ び最大酸素借に及ほす影䈏。平成元年度日本体育 協会スポーツ医科学研究報告, No. IV, 競技力向上 に関するスポーツカリキュラムの研究開発, (1990), 207-212.

23）高松 蓝. パワーアップ型とバルクアップ型の筋 カトレーニング. 臨床スポーツ医学, $(1991), 8$, 753-760. 